introduction of solid media by Koch has, of course, been of inestimable value in enabling us to secure pure cultures of the bacteria, it seems as though we have lost a great deal of valuable information by neglecting some of the older and less convenient methods of growing these organisms. It has been shown that certain bacteria which have the power of fermenting calcium citrate in a liquid medium will almost immediately lose this ability if transferred to a gelatinous medium. The bacteria pathogenic to rats lose their virulence if cultivated in contact with the air, and many other instances of the great rapidity with which these micro-organisms may modify their seemingly fixed functions might be given. I think enough has been said, however, to illustrate the fact that we really know very little about these most interesting and essential plants. That we shall be able to accomplish as much by selection with certain groups of bacteria as has already been done with the higher plants may seem too much to expect, but I believe it is certainly possible to improve greatly many processes in nature as well as in various industries dependent upon the bacteria by applying the knowledge and information gained from plant breeding in other lines.

\title{
BREEDING PROBLEMS.
}

By W. M. HaYs, U. S. Department of Agriculture.

The farmers of America produce annually nearly $\$ 5,000,000,000$ worth of products. Most of this vast production, say $\$ 4,000,000,000$, is handled by living forms of plant and anjmal life, which may be bred by man to greater efficiency. Many species can be so bred as to increase their production 25 per cent, and some only 10 per cent, without altering the other conditions of production. These other conditions of production can also be improved so as to increase production in nearly like amount. Broadly speaking, production can be increased 10 per cent by breeding better plants and better animals, and another 10 per cent by improving the methods of farming. In either case 10 per cent of $\$ 4,000,000,000$ is $\$ 400,000,000$, but the increase by better breeding can be had at a much less cost than the increase from better farming.

Betterments from breeding reproduce themselves and with no very great expense may be perpetuated and made continuously effective. Many of the betterments in the methods of farming, as the purchase of fertilizers and better cultivation, require considerable expenditure of money and labor every year. Burbank's potato, Gideon's Wealthy apple, Wilson's strawberry, Minn. No. 169 wheat, Cruikshank's Shorthorns, or the Jersey blood from the sire "Noble," go forward adding blessings year by year as a result of the work of the original breeder.

It is not argued that the wise purchase of commercial fertilizers does not pay good profits, nor that really superior cultivation and 
extra care wisely expended by the individual do not very materially increase the net profits of the farm. The point argued is that a reasonable amount of brains, money, and effort put into a study of the science of breeding and into well-directed, long-continued, systematic effort will pay much more than ordinary profits. That a large organized effort along this line will not only handsomely pay the present generation, but will leave a larger heritage for our children, has been abundantly proven. Every breeder of plants or of animals who, with a sufficiently large number of individuals for a reasonably large number of years, has pursued a plan of breeding, which would be accepted by those now best able to judge of methods, will agree that large improvements can be made at a cost which represents only a part of one per cent of the value of such improvements to the whole people. A still very much larger improvement can be effected by an expenditure of between 1 and 10 per cent of the possible additions to the value of our crops and live stock.

The work of breed and varjety improvements and of breed and variety formation is now going forward, but at a pace too slow for these times when the world is advancing with accelerated speed all along the line. As science, inventive genius, constructive skill, business organization, and great market demands at home and abroad have pushed forward things mechanical, so should ways be. found of improving these living things which serve as machines for transforming the substance of soil and air and the force of the sun's rays into valuable commodities. The problem of improving these living machines is not mechanical; it is vital. The energy of the generative cell, and its development into the mature plant or animal, is more abstruse and more profound than the mechanism of the mightiest locomotive. Here the controlling forces of one generation of these living machines plunge, spirit-like, through the microscopic generative cell and rise in the progeny, possibly the potencies of a single Shakespeare-like individual to be multiplied a million fold as a valuable new variety or breed. As one machine is more efficient than another, so the blood of one generative cell, or of a small group of generative cells combined into an efficient varietal or breed unit, is more valuable than another.

Our country has spent enormous sums to bring about the wonderful mechanical improvements made during the past century and a quarter. Through its patent laws it has granted temporary monopolies to inventors and manufacturers and the people have been most glad to pay the slightly higher prices for new inventions, in order that invention might go rapidly forward. Our patent laws have paid not 100 cents on the dollar, but ten thousand per cent on the cost which the people have thus paid in royalties. And it is worth noting that, while the mechanical side of our farm management has shared in this improvement, the theory, or philosophy, of agriculture has longer lagged behind. To build up the philosophies of farm management no patent-law scheme will apply. Private money cannot be induced to enter. The rewards cannot be controlled. The cost of investigation must be paid by the whole people 
participating in the expense as in developments of agriculture and experiment stations, the whole people enjoying the results. State and Government appropriations of money have been found necessary to secure investigation into the philosophies of the farm, and these direct appropriations are doing the work grandly. The scientists are learning of the soil, the plant, and the animal, are successfully attacking the problem of improving the general plan of the farm, and are starting hopefully to place farm management on a scientific engineering basis. The whole range of farm and farm home management in their general relations and in their specific parts are bejng studied by practical, trained investigators. And the business of farming and farm home making are being lifted up, as all the world is rising through improved industries, more general education, a wider diffusion of honesty and confidence, and a more universal Christian charity, into a better life, a grander civilization.

The experiment stations and the agricultural schools are working nearly as rapidly in their field as did the patent laws in theirs when they were only a third of a century old. When we have a consolidated school with a 10-acre school farm in every district 5 miles square, an agricultural high school with a half-section experiment farm in every 10 counties, and an agricultural college with its 1000 acres in every State, and all these thousands of demonstration and experiment farms and schools doing their full quota of work, they will no doubt accomplish more for farm and home management than our patent laws have done in the improvement of machinery.

The mechanical appliances are being improved and the cost is being easily met. The philosophies of agriculture are being wrought out and a scheme for educating all the country youth in agriculture and in home making is being organized, and all at a price which the whole people are glad to pay.

last but not least comes the improvement of our plant and animal forms and forces. Private initiative has proven unequal to the task. The possible increase in values is too vast to be left longer without public attention. The problem of securing an additional annual income of hundreds of millions of dollars is too great to be met by anything but large plans adequate for the work. Scientific methods have already been devised with which to undertake the task at many of its most important points. Scientific efforts in the laboratory and in the field will develop at once the better methods and the improved forms which will pay the bills. As in mechanical advancement, many unsuccessful trials will be made to each one that succeeds in producing a new value in plant or animal. But, as in mechanical invention, the profits resulting from the successes will annually many times over pay for all the expense for investigation and breeding for that year. It may not be too much to say that a dollar invested in plant and animal improvement will on the average produce more dollars than does a dollar invested by the whole people in mechanical improvements. Those best able to judge of the new organizing movement to invest large sums of public money in plant and animal improvement are unanimous in 
the belief that the improvement of plants and animals is such justifiable work that the public should undertake the task in a manner commensurate with the goal.

In a few of the patent laws it is possible to place the whole cost on those who use the new commodities. In case of experiment stations working out improvements in farming, nearly the whole cost is borne by the Government; the cost of our schools to build up farm life is borne by the Nation, the State, the locality, and those participating, all coöperating. Until very recently the expense of breeding animals, plants and bacteria was nearly all left to the individual, though the whole people finally received nearly all the benefit, too little going to those who created the new forms of wealth. There is no way of patenting new varieties of plants or new breeds of animals. Unlike machines those organizations naturally reproduce themselves, each after its own kind and in most cases with great rapidity.

The originator has but a very brief time in which to secure profits from new values he may have created. Very soon those to whom he first sold a new variety or a new breed can compete with him with plants or animals having the same blood values as his own stock. There is, therefore, no adequate private business interest behind the creation of new values to induce this work to go forward as rapidly as the general interest demands. Had there been greater profits accruing to breeders, the world would have had hundreds of Cruikshanks and Burbanks. The world has come to recognize that beneficial works which cannot be done by the individual must be done by the community. And the States and the National Government are finally taking hold of the improvement of plants and animals. Rather, they are coopperating with the other forces operating in this field of activity, and organizations are being formed for the collection of information, for the diffusion of information, for the projection of plans, for the encouragement of investigators and breeders, and for the correlation and better coördination of the forces all along the line. As a place for free open discussion of the best legislation, the proper functions to delegate to the National Department of Agriculture, to the State Experiment Station, to coöperative associations, to large breeding firms, to private breeders, to amateur breeders and scientists and to the stockman, dairyman, farmer, horticulturist, gardener, florist, and forester, a national society has recently been formed under the name "The American Breeders' Association." This is a democratic forum to which those in authority and those who are formulating new ideas go for an annual review, criticism and encouragement. There the man who sees visions of meritorious things should be welcome as well as the man who has the reality of a valuable new product for sale. Here, as in our. National and State institutions of research and education, science and practice may be compounded as nowhere else in the world.

This work of plant and animal improvement, and the investigations into the facts of heredity, will naturally be delegated and distributed to the various agencies named. The National Depart- 
ment of Agriculture can appropriately take a leading place in making the necessary theoretical investigations of the general facts and the theory of heredity and the breeding of plants and animals. It can also aid the research stations and the coopperative associations, also firms and private individuals in their work of variety and breed improvement and variety and breed formation. In fact, it can properly become more and more a great clearing house in which coöperation of groups of the various agencies named can operate. By putting Federal money behind plans of coöperation devised by workers in this central department, and by other persons, it can greatly aid in inaugurating coöperative enterprises which in the aggregate will be both extensive and most efficient. It can be a centre of information of means, of general helpful administration, and of actual productive work. The field is so broad that all available agencies should be built up, supported and made prominent each in its own field.

The breeding of plants and the breeding of animals for local conditions and for specific purposes are long-time propositions. Long-time breeding propositions require that the man and the species or variety be long kept together, and there must be made long-time plans and long tenure of office of the successful workers. The work cannot best be classified mainly about methods of work, but about problems. The problem and the man or group of men to attack the problem, are the units of enterprises. How to enlarge greatly the coöperative relations among all the agencies mentioned is up for solution and a unanimous desire is found thus to promote "team work" all along the line.

The State Experiment Stations are squaring themselves to take a prominent part in breeding. A valuable invention or a successful investigation usually is the product of a mind which starts with a theory and a desire and reaches in that particular line mastery. Likewise valuable improvements in plant and animal species are usually the result of the efforts of a mind which in a masterful way develops a useful blood line to fit a certain economic or artistic type of ideal, and for a particular purpose. True, some inventions are stumbled upon accidentally, some truths are inadvertantly discovered, and natural mutations of plants and animals likewise occasionally thrust themselves into notice. But most of the advances in breeding in the future are bound to be made under the system of scientific effort now being organized. And the experiment station being near the local problem of breeding plants and animals for each soil, climate, market, and other local condition, is a proper agency through which much of the work must be conducted. Centering much of this work at the experiment stations which are close to our colleges and schools of agriculture, places this work where it will have a large educational value. The presence of large wellconducted plant-breeding nurseries with the accompanying plat testing, seed growing, and seed and plant distribution of breeding herds, and of officers who aid in managing coöperative animal breeding associations, with the accompanying plant and animal breeding 
and testing laboratories, adds very greatly to the inspiring equipment which is growing up about our agricultural schools and colleges. But of highest importance is the development by these schools and colleges of agriculture of officials expert in the practical side of breeding, who become a source of inspiration as well as of information to the students. Our experiment stations have made only a faint beginning in the work of breeding, but that beginning is already on a sound basis. Illinois' work on corn improvement, Minnesota's work on corn, wheat, flax, etc., South Dakota's work on hardy fruits, North Dakota's work on rust-resistant flax, and other efforts have placed plant breeding on an economic basis in our experiment stations from which our States will not allow this movement to recede. Work in animal breeding in operation or projected in Missouri, Maine, Illinois, Colorado, Iowa, Minnesota, and other States will soon have placed the statjons in a soljd line in animal breeding also.

Just how the theoretjcal problems shall be taken up, how the stations coöperating with each other, with the Federal Department of Agriculture and with coöperative associations or with breeders shall approach the improvement of existing pure breeds or the formation of new breeds, are matters of detail which must be solved step by step. Our National and State legislatures evince a willingness to supply money to the National and State experiment stations with which not only to press forward investigations in breeding but to did in the work of actual breed and variety improvement and breed and variety formation. Breeding associations, and especially local coöperative organizations of persons breeding one or more kinds of plants or animals, probably are to have a large place in animal and plant improvement. The speaker is especially interested in any movements which may be contemplated along this line. County associations for breeding milking Shorthorns, Poland Chinas with large fecundity, cattle resistant to tuberculosis, cholera-resistant swine, business driving horses, tough draft horses, large-yielding corn, hardy apples, or other of the classes of animals and plants needed for a special locality or for general use are suggested organizations which may prove valuable. The organization of these associations, their method of owning lands, stock, and seeds by the association or by the individual members, the relation of these associations to the State Experiment Station and to the National Department of Agriculture, and a host of other related questions will rapidly rise for solution, because the movement is on, and the money with which to do the work is not very far out of sight.

Firms and individuals who undertake independently the breeding of plants and animals form a rapidly increasing class. The public through its National and State agencies can afford to coöperate with many of these people. A Burbank is so valuable to the country that the Carnegie institution has properly given him a grant of $\$ 10,000$ a year with which to enlarge his work. The National and State institutions mentioned are rightfully starting to do much to aid private breeders in finding and securing by importation where 
necessary the best available foundation stocks with which to begin breeding. And these institutions realizing that private as well as coöperative and public organizations will make wonderful use of practical information, are beginning to study the facts and philosophies of breeding and to publish them free to all workers.

As a general policy it would seem wise usually to have the ownership of valuable new plants and animals created by joint public and private effort vested at the earliest possible period of their distribution in private ownership, and that public moneys be expended rather in subsidizing the production of new values in pure-bred animals and in pure-bred plants than in plants and animals to be given away. Giving away new things is an easy kind of "damning with faint praise." Placing superior stocks of plants and animals on sale at prices which are fair yet which are enough above ordinary prices to form the basis to create and sustain classes of pure-bred animal breeders and pure-bred seed and plant growers, provides safe, conservative, and efficient agencies which for a moderate profit will bring the pure-bred seeds, plants, and animals to the largest possible number of people who will properly care for and make wide use of them. The larger present problems are the improvement of the great breeds of domestic animals and the largely used varieties of field crops, fruits, vegetables, and forest trees. In all these cases there are classes of people devoted to the multiplication and improvement of pure-bred stocks. Information, financial assistance, and supervision in a coöperative way would greatly increase the efficiency of their work.

The scientists and the practical men have begun to create a wonderful literature of breeding and our young people have in this subject another wonderful school study. It will soon be a culture study as well as a practical line of instruction. It will combine philosophy, art, industry, and even imagination into a most fascinating line of human conception. Its mysteries are deep, its objects interesting, its results are of high economic value. Its relations to man, his sustenance, his individual development, and his racial aspirations are of the highest importance.

\section{BREEDING DISEASE RESISTANT PLANTS.}

By W. A. Orton, U.S. Department of Agriculture.

Resistance to disease is a quality of fundamental importance in cultivated plants, which the farmer's interests should lead him to develop and maintain in all his crops. An examination into the history of our agriculture will show many instances where the cultivation of crops in certain localities has been temporarily or permanently abandoned because of the ravages of disease, for instance, the growing of grapes in certain sections on account of black rot 